\title{
Teacher's Reinforcement in Teaching English at the Second Year of State Islamic Senior High School 2 Kuantan Singingi
}

\author{
Dias Frahesti, Harum Natasha \\ Faculty of Education and Teacher Training, \\ State Islamic University of Sultan Syarif Kasim Riau, \\ Pekanbaru, Riau, Indonesia \\ Dias.frahesti@uin-suska.ac.id, harum.natasha@uin-suska.ac.id
}

\begin{abstract}
This research was aimed to find out the teacher's reinforcement in teaching English at the second year of State Islamic Senior High School 2 Kuantan Singingi. The subjects of this research were an English teacher and 5 students. This research was qualitative method with descriptive technique. In gathering the data, researcher distributed interview and observation to determine what components of reinforcement used by the teacher in teaching English. The result of this research showed that the English teacher at the second year of State Islamic Senior High School 2 Kuantan Singingi used verbal and non-verbal reinforcement in teaching English. For verbal reinforcement, the teacher used "reinforcement with words and reinforcement with sentence". For non-verbal reinforcement, the teacher used "gestural reinforcement, proximity reinforcement, contact reinforcement, activity reinforcement and token reinforcement". The reinforcement mostly often used by the teacher in teaching English is the reinforcement with words $(22 \%)$, whereas the reinforcement that is rarely used by the teacher is token reinforcement $(6 \%)$.
\end{abstract}

\section{Keyword: Teacher Reinforcement, Teaching English}

\section{A. Background of the Problem}

Formal education (school) is a process of planned and organized activities, consisting of teaching and learning activities and aims to produce positive changes in students who are heading toward maturity. Learning is a complex process and involves various interrelated aspects. Learning in school with all subjects taught to students requires an effective method to attract students' attention and interest in learning, including English lesson which is an important subject at school.
English is one language that is used as a communication tool that has an important role in every part of life. In the learning process, students should master English, but in many facts, students are less interested and consider English is difficult. Therefore, the teacher is required to be able to grow students' interest in learning English because the teacher is the main component in the teaching and learning process.

The teacher should bring the students to feel enjoyable in the process of teaching and learning. The success of learning mainly depends on teacher 
roles. It means that the teacher's way and style will greatly influence the students. If the teacher's way and style of teaching are interesting, the students will learn the subject taught by the teacher enthusiastically. Therefore, every teacher should have good strategies in the teaching and learning process.

The effectiveness of the teaching and learning process depends on how the teacher manages the students in the class (Wahyudi, 2013, p. 102). It is called classroom management. In this case, the teacher has the main role in maintaining classroom situations. Lewis (2013, p. 94) states that classroom management is the number one battle that a teacher must win in the classroom. It means that the teacher has to comprehend how to manage the classroom, such as: using an interesting strategy, controlling the students' behavior, and so on.

Many teaching strategies can be applied by the teacher. One of them is to provide reinforcement to the students. Reinforcement is given to improve students' interest in learning. According to Santrock (2011, p. 222), reinforcement is a consequence that increases the probability that a behavior will occur. While Woolfolk (2007, p. 225) said that reinforcement is the use of consequences to strengthen behavior. There are two types of reinforcement, positive reinforcement and negative reinforcement. Skinner (in Guy 2000, p. 101) states that positive reinforcement is called reward and negative reinforcement is called relief. Reward or reinforcement is a behavior that leads to desirable outcomes, it is more likely to occur in the future situation (Skinner, 2014 , p. 184). The reward is one of the strategies that can be used by the teacher because it can increase interest in learning and motivation to achieve satisfactory student achievement. Reward is also provided a positive stimulus to students. Negative reinforcement is any stimulus removal which increases the likelihood of particular behavior (Hoque, 2013, p. 13). In conclusion, giving reinforcement in the learning process can increase students' interest in learning English.

State Islamic Senior High School 2 Kuantan Singingi is one of the schools in Kuantan Singingi regency. As a formal educational institution, this school also presented English as one of the subjects. The researcher's reason in considering state Islamic Senior High School 2 Kuantan Singingi as the source of the data in this research was that because this school implemented reinforcement in teaching English. The English teachers implemented the reinforcement to improve students' interest in the learning process. But the students still have some problems in English, especially from eleventh grades.

Based on the preliminary study by interviewing the English teacher at XI Grade at State Islamic Senior High School 2 Kuantan singingi, the researcher got some information that some of the students unconcerned with teachers' explanations in the teaching learning process. They talked to their friends when the teacher explains the lesson. Some of the students could not give positive feedback in English classes. They could not answer the questions given by the teacher. Some of the students had low motivation in learning English. They seemed to be sleepy during the lesson. Some of the students also got low scores in English subject.

The weaknesses mentioned above the researchers want to find out the components of reinforcement used by the teacher in teaching English at the 
second year of the State Islamic Senior High School 2 Kuantan Singingi.

Based on the problems that exist in Eleventh Grade at State Islamic Senior High School 2 Kuantan Singingi, the researcher found the following phenomenon:

1. Some of the students unconcerned with teachers' explanations in the learning process.

2. Some of the students cannot give positive feedback in English classes.

3. Some of the students have low motivation in learning English.

4. Some of the students got low scores in English subject.

Based on the problem illustrated above, the researcher is interested in investigating the problems into research entitled "Teacher's Reinforcement in Teaching English at the Second Year of State Islamic Senior High School 2 Kuantan Singingi”.

\section{B. Research Problem}

The problems of this research was formulated in the research question: what are the components of reinforcement used by the teacher in teaching English at the second year of State Islamic Senior High School 2 Kuantan Singingi?

\section{LITERATURE REVIEW}

a. Reinforcement

Reinforcement is one strategy that is widely used by teachers in the learning process to increase student motivation and interest. Santrock (2011, $\mathrm{p}$ 222) stated that reinforcement is a consequence that increases the probability that a behavior will occur. While Alma (2014, p. 40) defines reinforcement is a positive response to a particular behavior from students that allows the behavior to reappear. The same tone is also stated by Woolfolk (2007, p. 225), reinforcement is used of consequences to strengthen behavior.

Reinforcement commonly used by the teachers in teaching process is positive reinforcement such as praises and rewards. According to Hogue (2013, p. 13), the concept of reinforcement is identical to the presentation of a reward reinforce with the stimulus the presentation or removal of which increases the probability of a response being repeated. While Santrock (2011, p. 222) defines positive reinforcement as reinforcement based on the principle that the frequency of a response increases because it is followed by a rewarding stimulus.

\section{b. The Types of Reinforcement}

1) Positive Reinforcement

Woolfolk (2007, p. 225) states that positive reinforcement is strengthening behavior a desired stimulus after the behavior. Positive reinforcement is the presentation of a stimulus that increases the probability of a respond (Zhou, 2017, p 8). The positive reinforcement often occurs in the classroom. Many teachers used positive reinforcement in the learning process because it is easy to apply.

\section{2) Negative}

\section{Reinforcement}

According to Woolfolk (2007, p. 226), negative reinforcement is strengthening behavior by removing an aversive stimulus when the behavior occurs. Guy (2000, p. 100) states that negative reinforcement occurs when the probability that a response will occur increases as a function of something being taken away from a situation. 
Some teachers consider negative reinforcement is a punishment given to suppress a students' behavior, but the assumption about that is wrong because the process of reinforcement (positive and negative) always involves strengthening behavior. Santrock (2011, p. 222) states that punishment is a consequence that decreases the probability that a behavior will occur. Punishment is used as an unpleasant stimulus to weaken or suppress behavior (Woolfolk 2007, p.226). It means that reinforcement and punishment are different, but reinforcement and punishment are types of consequences of behavior.

\section{c. The Components of Positive Reinforcement}

According to Alma (2014, p. 41), there are some components of positive reinforcement that are:

1) Verbal reinforcement

The teacher gives a positive comment to the students in form of words and sentence such as "good", "great", "smart", "your answer is correct" and " thank you, you are very smart".

2) Gestural Reinforcement

The teacher reinforces

the students by using expressions and gestures such as giving a smile, giving applause, giving thumbs up and nodding the teacher's head.

3) Proximity Reinforcement

In this type of reinforcement, the teacher shows the attention to the students such as they stand close to the students or sit down beside the student seat.

4)Contact Reinforcement

Contact reinforcement means that the teacher gives a contact to the students to show their award such as teacher tapped students back or teacher caressed students head.

5) Activity reinforcement

In

activity reinforcement, the teacher can provide activities or tasks that are liked by the students such as listening to music, telling stories, etc.

6) Token Reinforcement

This type of reinforcement is shown by the teacher such as making comments on student papers, giving picture cards, and giving gifts to students.

The same tone also sated by Helmiati (2013, p. 74) there are some components of positive reinforcement that are:

1) Verbal Reinforcement

Verbal reinforcement is a comment in the form of praise, support, recognition and encouragement used to strengthen the behavior and appearance of the students. Reinforcement can be in the form words and sentence.

2) Non-Verbal Reinforcement

a) Gestural Reinforcement

Gestural reinforcement such as proud expressions, smiles, thumbs up and applause.

b) Proximity Reinforcement Proximity reinforcement is the teacher approaches students to show the teacher's attention to the students.

c) Contact Reinforcement

This reinforcement can be in the form of tapping students' shoulders, shaking 
hands and raising students' hand.

d) Activity Reinforcement

Activity reinforcement is giving assignments and activities that are liked by the students.

e) Token Reinforcement

Token reinforcement such as written comments on student books, picture cards, plastic stars and gifts. Giving gifts should not be done too often so students do not always expect rewards.

\section{d. The Schedules of Reinforcement}

According to Hoque (2013, p. 13), the schedules of reinforcement are:

1) Continuous Reinforcement Schedule: It is an arrangement of providing reinforcement after every correct response. For example, a student may be rewarded for every correct answer.

2) Fixed Interval Reinforcement Schedule: It is an arrangement of providing reinforcement after a set interval of time, e.g., every 3 minutes or every 5 minutes. How many times he has given correct responses during this fixed interval of time does not matter. It is only at the expiry of the fixed interval that he is presented with some reinforcement.

3) Fixed Ratio Reinforcement Schedule: It is an arrangement of providing reinforcement after a fixed number of responses. For example, a rat might be given a pellet of food after a certain number of lever presses. A student may be properly rewarded after he answers a fixed number of questions say 3 or 5 . It is used in some factories by employers of casual workers or laborers where wages are paid on a piece- work basis that is the number of garments sewn or the number of baskets or boxes packed.

4) Variable Reinforcement Schedule: It is an arrangement of providing reinforcement after a varying interval of time or after a varying number of responses. In this case, reinforcement is irregular. The individual does not know when he is going to be rewarded and consequently he remains motivated throughout the learning process in the hope of reinforcement. The most common example of such a schedule is gambling. Here rewards are unpredictable and keep the players wellmotivated through occasional returns

\section{e. The Function of Reinforcement}

Using reinforcement in the classroom has a positive influence on the learning process. According to Helmiati (2013, p. 74), the functions of giving reinforcement as follows:

1) To make students more confidence.

2) To increase students' motivation, interest and attention to learning.

3) Arouse and maintain student behavior.

4) To maintain conducive learning. 
Meanwhile Usman (2010, p. 81) mentioned the functions of reinforcement for students are:

1) To increase students' attention in learning.

2) To stimulate and increase student learning motivation.

3) To improve learning activities and fostering productive student behavior

\section{Operational Concept}

The operational concept is used to give limitations to the theoretical framework to avoid misunderstanding and misinterpretation in this research. The operational concept is a concept consist of some indicators that guide the research to measure some related aspects of variable $X$, it should be interpreted into particular words to be easier measured. According to Syafi'I (2015, p. 24), all related theoretical framework can be operated in the operational concept. There is one variable in this research, they are teacher's reinforcement in teaching English at the second year of state Islamic senior high school 2 Kuantan Singingi.

According to Alma (2014, p. 41), there are several indicators to measure the reinforcement used by the teacher in teaching English as follows:

1. Verbal reinforcement

2. Gestural reinforcement

3. Proximity reinforcement

4. Contact reinforcement

5. Activity reinforcement

6. Token reinforcement

\section{E. RESEARCH METHOD}

This research was a qualitative research design consisting of one variable that is teacher's reinforcement in teaching English. This research aims to describe the teacher's reinforcement in teaching English at State Islamic Senior High School 2 Kuantan Singingi. Ary (2010, p. 125) said that qualitative research seek to understand phenomenon by focusing on the total picture rather than breaking it down into variables. Qualitative research is best suited to address a research problem in which you do know the variables and need to explore (Creswell, 2012, p. 16). This research was conducted at State Islamic Senior High School 2 Kuantan Singingi. It was located on Datuk Keramat street, Kuantan Singingi. This research was held on October till November 2019

\section{a. Participants of the Research}

The target participants in this research were the English teacher and students of the science class at the second year of State Islamic Senior High School 2 Kuantan Singingi in 2018/2019 in academic year. They consisted of 1 English teacher and 5 students of the science class at the eleventh grade of State Islamic Senior High School 2 Kuantan Singingi. The total students of the science class at the eleventh grade were 24 Students and the researcher used purposeful sampling to select the students as participants. Creswell (2012, p. 206) stated that purposeful sampling is the way the reseracher selects the participant in qualitative study, which in this strategy the researcher intentionall elect individuals and sites who the researchers understand the phenomenon. The researcher took one teacher as respondents to collect the data because in the eleventh science grade there was only one English teacher. Her name is Dahlia Abda, she 
graduated from UNRI. She has taught at State Islamic Senior High School 2 Kuantan Singingi since 2015.

\section{b. The Technique of Data Collection \\ To get the data needed to} support this study, the researcher used interview and observation to collect the data.

\section{Interview}

One of the most popular techniques to obtain in research by asking respondent orally is an interview. Arikunto (2006, p. 227) said interview is a dialogue done by an interviewer, to gain information as many as possible from an interviewee. The question interviews are not arranged rigidly before conducting interview but they should be suitable for the condition and with the unique characteristics of the informants or interviewer (Moleon, 2006, p. 187). It is conducted as people talk one to another in daily communication.

The researcher made an interview with an English teacher and students of State Islamic Senior High School 2 Kuantan Singingi. The topic of interview was about teacher's reinforcement in teaching English at the eleventh grade students of State Islamic Senior High School 2 Kuantan Singingi.

\section{Observation}

The observation focused on teacher's reinforcement in teaching English. According to Arikunto (2006, p. 226), observation is an effective way to complete the research with observation form as an instrument. Creswell (2012, p. 213) states that observation is the process of gathering open-ended, firsthand information by observing people and places at the research site.

\section{c. Techniques for Analyzing Data}

In qualitative research, techniques for analyzing the data were used to synthesize the data collected from various sources into a coherent description of what the researcher had been observed and discovered. Regarding with this research, the researcher used data analysis based on Miles and Huberman Model (1994, p. 10). In the system, the researcher always moves among three components of analysis during the data collection. After collecting data, the researcher moves among the three components of data analysis by using the rest of the time.

\section{Reduction of the Data}

Data reduction can be interpreted as the process of selection, simplification, and transformation on the data to the field notes when the researcher research the teacher's reinforcement in teaching English in the field note. Then after this, the researcher gets some data of teacher's reinforcement from the English teacher and students and the researcher selects the data related to the research problem taken from the source of data. Then the researcher focused on each research problem the simplifying of the data in the field note.

\section{Display of the Data}

Data display is a set of information which has been classified and organized based on the data reduction which leads to conclusion. Generally, a display is an organized, composed assembly of 
information that permits conclusion drawing and action. By displaying data, the researcher considers what she should do, she could analyze based on her understanding. The researcher got some information about teacher's reinforcement from English teacher and students then the researcher explained about teacher's reinforcement in teaching English with the description and the researcher made some conclusion from the informant.

\section{Verification of Data}

The last step is
concluding and giving
suggestions based on the data analysis. It is explaining the meaning of the data, in fact, the researcher inferred the research finding into a single overall conclusion accordingly to research data and the verification is explained the meaning of the data in fact observation to know teacher's reinforcement in teaching English.

\section{F. RESEARCH FINDING AND DISCUSSION}

\section{Research Findings}

This section presents findings on teacher's reinforcement in teaching English at the second year of State Islamic Senior High School 2 Kuantan Singingi, the reinforcement divided into two indicators including verbal reinforcement and non-verbal reinforcement. The researcher used interviews and observations as guidelines.

\section{a. Verbal Reinforcement}

In this indicator, the researcher emphasizes observations on two subindicators, namely reinforcement with words and reinforcement with sentences.

1) Reinforcement with words

Reinforcement with words is reinforcement that can be expressed in the form of praise. Based on the results of an interview with an English teacher about reinforcement with words, the researcher found that the teacher applied reinforcement with words in teaching English. The teacher gave praise to the students who can answer the question correctly. Reinforcement with words given by the teacher was varied such as good, smart, great, etc. This was proved by the interview data with an English teacher as follows:

The researcher :

$$
\begin{aligned}
& \text { apakah ibuk pernah } \\
& \text { memberikan komentar } \\
& \text { kepada anak seperti: } \\
& \text { bagus, pintar, hebat dan } \\
& \text { lain sebagainya saat } \\
& \text { siswa dapat menjawab } \\
& \text { pertanyaan dengan } \\
& \text { benar? } \\
& \text { (Have you ever given } \\
& \text { any comments such as } \\
& \text { good, smart, great, etc. } \\
& \text { in the class?) }
\end{aligned}
$$

The teacher

Oke, ini sebentuk reward kita kepada anak berarti ya eee... untuk setiap masuknya ini hampir selalu miss berikan kepada anak, baik itu memuji anak nanti dalam kata bagus, great, good excellent 
Dias Frahesti, Harum Natasha - Teacher's Reinforcement in Teaching English at the Second Year of State Islamic Senior High School 2 Kuantan Singingi....

\begin{abstract}
dan segala macamnya. Memang ada ini ya.

(This is like any rewards that we give to the students, eee..

In the learning process in the class I always reinforce them by using good words such as great, good, excellent, etc.)
\end{abstract}

The interview excerpt above confirms that the teacher often used reinforcement with words, these were supported by the statements from the five students. They stated that they often received reinforcement with words from the teacher in the learning process as follow:

The researcher:

$$
\begin{aligned}
& \text { Apakah adik pernah } \\
& \text { diberi pujian seperti: } \\
& \text { bagus, pintar, hebat dan } \\
& \text { lain-lain ketika } \\
& \text { menjawab pertanyaan } \\
& \text { dengan benar? } \\
& \text { (Did your teacher give } \\
& \text { praise such as good, } \\
& \text { smart, great, etc. when } \\
& \text { you can answer the } \\
& \text { questions correctly?) }
\end{aligned}
$$

Student 1:

Pernah, mmm... saya pernah diberi pujian oleh miss Dahlia ketika menjawab pertanyaan dengan benarseperti bagus, pintar, hebat dan lain-lain.

(Yes I have received praise such as good, smart, great, etc. when answering the questions correctly.)

Student 2:

Iya saya pernah eee... mendapat pujian seperti bagus, pintar, hebat dan lain-lain ketika dapat menjawab pertanyaan dengan benar.

(Yes I have received praise such as good, smart, great, etc. when answering the questions correctly.)

Student 3:

Pernah.

(Yes I have.)

Students 4:

Pernah miss.

(Yes I have.)

Student 5:

Iya saya pernah diberikan pujian.

(Yes I have received the praise.)

To strengthen the results of the research, the researcher also collected the data by observation. Based on the observation, the researcher found that the teacher uses reinforcement with words in teaching English as follows:

Table IV.1

Data Reinforcement with Words

\begin{tabular}{clllll}
\hline indicator & Sub indicators & 1 & 2 & 3 & 4 \\
& & & & & \\
& Sood & $\sqrt{ }$ & $\sqrt{ }$ & $\sqrt{ }$ \\
& Smart & $\sqrt{ }$ & $\sqrt{ }$ & $\sqrt{ }$ & $\sqrt{ }$ \\
& & & & & \\
\hline
\end{tabular}




\begin{tabular}{ll} 
Great & $\sqrt{-}-\sqrt{ }$ \\
\hline
\end{tabular}

2) Reinforcement with sentence

Reinforcement with sentences is reinforcement that can be expressed in the form of praise sentences. Based on the results of the interview with an English teacher about reinforcement with sentences it can be concluded that the teacher applies reinforcement with sentences in teaching English. The teacher gave praise to the students who can answer the question correctly. Reinforcement with sentences given by the teacher varies such as your answer is correct, thank you, you are very smart, etc. This was proved by the interview data with an English teacher as follows:

The researcher:

"Apakah miss pernah memberi komentar kepada anak berupa kalimat seperti: jawabanmu tepat sekali, terimakasih kamu sangat pandai dan lain-lain saat siswa dapat menjawab pertanyaan dengan benar?

(Have you given any comment such as your answer is correct, thank you, you are very smart, etc. when the students can answer questions correctly?)

The teacher:

$y a$, pernah, sering juga, terutama karena kami baru siap dengan bab ke 3, itu kami baru menyelesaikan tentang invitation letter dengan invitation card, ini ada juga dengan beberapa contohnya. Nah itu kalau memang bagus memang diberikan komentar seperti yaaa... you are so excellent, ya... kamu sangat pandai dengan segala macamnya.

(Of course, I ever to say for example in our last meeting in chapter 3 it is about invitation letter. In the learning process if the students do their task or answering questions correctly I always praise them, such as you are excellent.)
The interview excerpt above confirms that the teacher often used reinforcement with sentence, these were supported by the statements from the five students. They stated that they often received reinforcement with sentences from the teacher in learning as follow:

The researcher:

Apakah adik pernah diberi komentar berupa kalimat seperti: jawabanmu tepat sekali, terimakasih kamu sangat pandai dan lain-lain ketika dapat menjawab pertanyaan dengan benar? (Did your teacher give any comment such as you are right, thank you, you are so smart, etc. when you can answer the questions correctly?)

Student 1:

Pernah, Miss Dahlia pernah memberi kalimat seperti tepat sekali, terimakasih kamu sangat pandai ketika dapat menjawab pertanyaan dengan benar.

(Yes I have, the teacher gave me comments such as your answer is right, thank you, you are very smart, etc. when answering the question correctly.)

Student 2:

Pernah, Miss Dahlia pernah mmm... memberi saya komentar seperti kalimat jawabanmu tepat sekali, terimakasih kamu sangat pandai dan lain ketika dapat menjawab pertanyaan dengan benar.

(Yes I have, the teacher gave me comments such as your answer is correct right, thank you, you are very smart, etc. when answering the question correctly.)

Student 3:

Iya pernah juga.

(Yes I have.)

Student 4:

Alhamdulillah Miss, pernah mendapat pujian.

(Alhamdulillah, I have received the praise.)

Student 5: 
Iya, saya pernah diberikan komentar seperti itu.

(Yes I have received the comments like that.)

To strengthen the results of the research, the researcher also collected the data by observation. Based on the observation, the researcher found that the teacher uses reinforcement with sentences in the teaching process as follows:

Table IV.2

Data Reinforcement with Sentence

\begin{tabular}{|c|c|c|c|c|c|}
\hline indicator & Sub indicators & 1 & 2 & 3 & 4 \\
\hline \multirow{3}{*}{$\begin{array}{l}\text { Reinforcement } \\
\text { with sentences }\end{array}$} & Your answer is correct & - & $\sqrt{ }$ & $\sqrt{ }$ & $\sqrt{ }$ \\
\hline & $\begin{array}{l}\text { Thank you, you are very } \\
\text { smart }\end{array}$ & - & - & $v$ & $\sqrt{ }$ \\
\hline & You so excellent & $\sqrt{ }$ & - & $\sqrt{ }$ & - \\
\hline
\end{tabular}

\section{b. Non-Verbal Reinforcement}

In this indicator, the researcher emphasizes observations on five subindictors, namely gestural reinforcement, proximity reinforcement, contact reinforcement, activity reinforcement and token reinforcement.

1) Gestural reinforcement

Based on the results of the interview with an English teacher about gestural reinforcement, it can be concluded that the teacher also applied gestural reinforcement in teaching English. The teacher reinforces to respond student behavior. Gestural reinforcement used by that teacher such as smile, thumbs up and applause. This was proved by the interview data with an English teacher as follows:

The researcher:
Apakah miss
memberikan
penghargaan dengan
senyum maupun
gerakan badan seperti
acungan jempol kepada
siswa yang berani
menjawab pertanyaan?

(Did you reward them like smiling at them or gestural such as give them thumbs up when the students can answer the question correctly?)

The teacher:

Selalu, sesuai tadi dengan observasi juga dalam mengajar memang senyuman, body language, dengan mendampingi anak, menghampiri anak, itu memank selalu miss lakukan kepada anak ya. (Of course, in teaching the students, commonly I always used body language to the students such as, walking towards to the students or smiling at them.)

The researcher:

Bagaimana cara miss memberikan

penghargaan dengan mimic dan gerakan 
Dias Frahesti, Harum Natasha - Teacher's Reinforcement in Teaching English at the Second Year of State Islamic Senior High School 2 Kuantan Singingi....

badan selain senyum dan acungan jempol?

(Did you give them any gestural reinforcement besides smiling and give thumbs up to the students?)

The teacher:

$Y a$, dengan biasanya memegang pundak anak, memegang tangan anak, dengan segala macamnya atau anak yang sering pemalu itu kadang miss yang memotivasinya untuk ebih unggul dalam bilangnya masingmasing.

(Commonly, besides give them thumbs up I also tapping hand on their back especially for the shame students. Is the way I motivate the shame students in the class.)

The interview excerpt above confirms that the teacher also used gestural reinforcement, these were supported by the statements from the five students. They stated that they often received gestural reinforcement from the teacher in the learning process as follow:

The researcher:

Apakah adik pernah diberi senyuman ketika adik berani mengungkapkan pendapat?

(Has your teacher given smiling when you dare to express your opinion?)

Student 1:

Pernah, Miss Dahlia sering memberikan senyuman kepada saya katika berani
mengungkapkan

pendapat.

(Yes, the teacher gave

me a smile when I

express my opinion.)

Student 2:

Ya pernah, Miss Dahlia sering memberi saya senyuman ketika saya mengemukakan pendapat saya.

(Yes, the teacher gave me a smile when I express my opinion.)

Student 3:

Pernah, diberikan senyuman pernah.

(Yes I have, the teacher smiled at me.)

Student 4:

mmm... Alhamdulillah Miss, sering mendapat senyuman dari Miss.

(Mmm... Alhamdulillah, I often get a smile from the teacher.)

Student 5:

Iya saya pernah juga. (Yes I have too.)

The researcher:

Apakah adik pernah diberi acungan jempol atau tepukan tangan saat menjawab soal dengan benar?

(Has your teacher given thumbs up or applause when you can answer the question correctly?)

Student 1:

Pernah, tapi lebih sering diberi tepukan tangan saat menjawab pertanyaan dengan benar. 
(Yes I have, but I often got applause when answering the questions correctly.)

Student 2:

Pernah mmm... saya pernah diberi acungan jempol dan tepuk tangan. Tapi lebih sering tepuk tangan dari pada acungan jempol ketika menjawab soal dengan benar.

(Yes I have, mmm ... the teacher gave me the thumbs up and applause, but the teacher gives me the thumbs up more than applause.)
Student 3:

Pernah, diacungi jempol pernah dan yang lain juga pernah.

(Yes I have, the teacher gave me thumbs up, etc.)

Student 4:

Pernah Miss.

(Yes I have.)

Student 5:

$Y a$, saya pernah. (Yes I have.)

To strengthen the results of the research, the researcher also collected the data by observation. Based on the observation, the researcher found that the teacher uses gestural reinforcement in teaching English as follows:

Table IV.3

Data gestural reinforcement

\begin{tabular}{llllll}
\hline \multirow{2}{*}{ Indicator } & \multicolumn{1}{c}{ Sub indicator } & 1 & 2 & 3 & 4 \\
\hline Gestural reinforcement & Smile & $\sqrt{ }$ & $\sqrt{ }$ & $\sqrt{ }$ & $\sqrt{ }$ \\
& Applause & $\sqrt{ }$ & & $\sqrt{ }$ & $\sqrt{ }$ \\
& Thumbs up & $\sqrt{ }$ & $\sqrt{ }$ & & $\sqrt{ }$ \\
& & & & & \\
& &
\end{tabular}

a. Proximity reinforcement

Based on the results of the interview with an English teacher about proximity reinforcement, it can be concluded that the teacher also applied proximity reinforcement in teaching English to motivated the students. Proximity reinforcement used by the teacher such as the teacher stands close to the students and sits down beside the students. This is evidenced by the interview with an English teacher as follows:

The researcher:

Kapan miss memberikan penguatan kepada siswa dengan cara mendekati?
(Commonly, when will you give proximity reinforcement to the students in the class?)

The teacher:

Ketika mungkin anak itu lagi down dia biasanya, atau tidak focus atau memang setiap mauk miss lakukan sama anak, baik anak itu sedang tidak ini... sedang tidak apaa... eee.. badnya lagi buruk atau badnya lagi baik itu selalu miss hampiri. Apalagi anak sedang ada masalah.

(I often reinforce them when they do not focus on learning in the class or sometimes in the middle of the learning process when the students get bored I reinforce them by using proximity reinforcement.) 
Dias Frahesti, Harum Natasha - Teacher's Reinforcement in Teaching English at the Second Year of State Islamic Senior High School 2 Kuantan Singingi....

The researcher:

Apakah miss pernah duduk atau berdiri di dekat siswa saat siswa mengerjakan soal?

(Have you ever sit or stand up close to the students when they are doing their assignment?)

The teacher:

Ya, ini juga sudah kita bahas ya memang miss lakukan.

(Yes I have, this was also discussed earlier.)

The interview excerpt above confirms that the teacher also used proximity reinforcement, these were supported by the statements from the five students. They stated that they often received proximity reinforcement in the learning process as follows:

The researcher:

Apakah miss pernah mendekati siswa dalam memberi penguatan?

(Has your teacher ever approached the students in giving reinforcement?)

Student 1:

Pernah, miss Dahlia pernah memberikan penguatan kepada kami.

(Yes the teacher has.)

Student 2:

Pernah.

(Yes the teacher has.)

Student 3:

Pernah, rata-rata kami diberikan penguatan dengan Miss mendekati kami bila kami sedang belajar.

(Yes the teacher has, usually the teacher give reinforcement by approaching, when we are leaning.)

Student 4:

Pernah Miss.
(Yes the teacher has.)

Student 5:

$\mathrm{Ya}$, Miss pernah juga memberikan penguatan.

(Yes, the teacher also gave reinforcement.)

The researcher:

Bagaimana caranya miss biasanya mendekati siswa?

(How does your teacher usually approach the students?)

Student 1:

Seperti mendekati kami, memberi nasehat dan lain sebagainya.

(Like approaching us, giving advise etc.)

Student 2:

Dengan cara berjalan mendekati siswa dan memberinya motivasi.

(By walking towards students and providing motivation.)

Student 3:

Miss mendekati kami ketika kami sedang menulis ataupun sedang membaca dan kami lalu apabila kami ada kemalasan diberikan semangat.

(The teacher approached us when we are writing or reading and if we are lazy we would be encouraged.)

Student 4:

Berjalan mendekati siswa dan memberi motivasi.

(By walking towards students and providing motivation.)

Student 5:

mmmm... Miss mendekati siswa dengan... dengan motivasi.

(Mmm ... the teacher approaches the students by providing motivation.) 
Dias Frahesti, Harum Natasha - Teacher's Reinforcement in Teaching English at the Second Year of State Islamic Senior High School 2 Kuantan Singingi....

To strengthen the results of the research, the researcher also collected the data by observation. Based on the observation, the researcher found that the teacher uses proximity reinforcement in teaching English as follows:

Table IV.4

Data Proximity Reinforcement

\begin{tabular}{|c|c|c|c|c|c|}
\hline Indicator & Sub Indicators & 1 & 2 & 3 & 4 \\
\hline \multirow{3}{*}{$\begin{array}{l}\text { Proximity } \\
\text { reinforcement }\end{array}$} & Walking towards student & $\sqrt{ }$ & $\sqrt{ }$ & $\sqrt{ }$ & $\sqrt{ }$ \\
\hline & Standing near student & $\sqrt{ }$ & - & $\sqrt{ }$ & $\sqrt{ }$ \\
\hline & Sitting near groups & - & $\sqrt{ }$ & - & - \\
\hline
\end{tabular}

b. Contact Reinforcement

Based on the results of the interview an English teacher about contact reinforcement, it can be concluded that the teacher also applied contact reinforcement in teaching English. Contact reinforcement used by the teacher such as teacher tapped students back, shake hands and high five. This was proved by the interview data with the English teacher as follows:

The researcher:

Apakah miss pernah menepuk pundak atau bahu anak untuk menguatkan anak?

(Have you ever reinforced them by tapping students back?)

The teacher:

Oke, ini juga sudah kita bahas tadikan bagaimana cara miss memberikan komentar dengan body language dan ini memang iya miss lakukan, diberi elusan atau tepukan pundak ya memank iya.
$(\mathrm{Ok}$, like I told to you before that, I tapped back on their back to reinforce them.)

The researcher:

Bagiamana dengan berjabat tangan atau melakukan tos. Apakah miss juga melakukannya?

(How about shake hands or high five, did you implement it to the students?)

The teacher:

Iya pernah juga, nah ini kemaren ini mungkin memang diluar drai materi, sebentuk anak itu dia pernah ikut lomba dalam cabang cerdas cermat tentang kebudayaan Kuantan Singingi dan kita masuk ke final, itu memang miss memang menyalami anak, memank menyuruh anak itu berdiri dan mempersilahkan anak yang lain memberi sebnetuk yaa... give applause dan segala macamnya. 
Dias Frahesti, Harum Natasha - Teacher's Reinforcement in Teaching English at the Second Year of State Islamic Senior High School 2 Kuantan Singingi....

(Yeah of course I have, I did it in the learning process in the class to warming up the atmosphere in the class and then sometime for the students who reach good academic, I always shake hands and praise them in the sometime as my appreciation to them.)

The interview excerpt above confirms that the teacher used contact reinforcement, these were supported by the statements from the five students. They stated that they often received contact reinforcement in the learning process as follows:

The researcher:

Apakah adik pernah dielus/ ditepuk pundaknya oleh miss atas prestasi mu dikelas?

(Has your teacher tapped your shoulder for your achievements in the class?)

Student 1:

Pernah miss, seperti di tepuk pundaknya aaa... atas prestasi di dalam kelas.

(Yes I have.)

Student 2:

Pernah, Miss Dahlia pernah mengelus pundak saya ketika mendapat prestasi di kelas.

(Yes I have, the teacher did that.)

Student 3:

Pernah, saya melihat Miss juga menepuk pundak kawan-kawan yang lain bila kawankawan mendapat prestasi dikelas.

(Yes, I saw the teacher tapping the shoulders of other students, if the students get achievements in the class.)

Student 4:

Alhamdulillah sering Miss.

(Alhamdulillah often Miss.)

Student 5:

$Y a$, Miss pernah menepuk pundak siswa dikelas.

(Yes, the teacher tapped the shoulder of the student in the class.)

The researcher:

Apakah adik pernah melihat miss menjabat tangan siswa atau melakukan tos atas prestasinya di kelas?

(Have you ever seen your teacher shake hands or high five with the students for their achievements in the class?)

Student 1:

Pernah, Miss Dahlia pernah menjabat tangan siswa atas prestasinya didalam kelas.

(Yes the teacher has.)

Student 2:

Pernah, saya melihat Miss eee... menjabat tangan siswa atas prestasinya. 
Dias Frahesti, Harum Natasha - Teacher's Reinforcement in Teaching English at the Second Year of State Islamic Senior High School 2 Kuantan Singingi....

(Yes I have, I saw the teacher shaking

students' hands.)

Student 3:

Pernah, Miss tos bila kami ada prestasi didalam kelas.

(Yes I have, the teacher high five if we get achievement in class.)

Student 4:

Pernah Miss, biasanya Miss berjabat tangan dengan siswa.
(Yes I have, usually the teacher shakes hands with the students.)

Student 5:

$Y a$, Miss pernah juga. (Yes, the teacher also did that.)

To strengthen the results of the research, the researcher also collected the data by observation. Based on the observation, the researcher found that the teacher uses contact reinforcement in teaching English as follows:

\section{Data Contact Reinforcement}

\begin{tabular}{llllll}
\hline \multicolumn{1}{c}{ indicator } & \multicolumn{1}{c}{ Sub Indicators } & 1 & 2 & 3 & 4 \\
\hline Contact & Tap the student's shoulder & $\sqrt{ }$ & - & $\sqrt{ }$ & $\sqrt{ }$ \\
reinforcement & High five & $\sqrt{ }$ & - & - & $\sqrt{ }$ \\
& Shake hands & & & $\sqrt{ }$ & \\
& & - & - & & - \\
& & & &
\end{tabular}

c. Activity Reinforcement

Based on the results of the interview an English teacher about contact reinforcement, it can be concluded that the teacher also applied activity reinforcement in teaching English. Activity reinforcement used by the teacher such as storytelling, games or quiz and learning outside. This was proved by the interview data with the English teacher as follows:

The researcher:

Apakah miss pernah memberikan penguatan melalui kegiatan yang menyenangkan bagi siswa dalam pembelajaran?

(Did you ever reinforce them by using activity reinforcement in the learning process?)
The teacher:

Ya... hehe.. sebagai tadi contohnya dengan observasi, hal yang menyenangkan itu miss lebih membawa faktafakat yang dekat seperti mungkin menjelaskan atau memberi contoh, miss lebih memberikan apa yang terkenal di Kabupaten Kuantan Singingi, apa yang dekat di kecamatn pangean, itu yang kita angkat, nah itu tadi kita ambil tentang Pantai Jai-Jai Raok yang mereka memang tau tentang ini, nah itu yang kita angkat tadi eee... di proses belajar mengajar tentang membuat teks 
Dias Frahesti, Harum Natasha - Teacher's Reinforcement in Teaching English at the Second Year of State Islamic Senior High School 2 Kuantan Singingi....

\begin{abstract}
an exposition dan disitu anak itu merasa senang karena dia tau karena kita bercerita juga. (Yeah usually to make the students more interested to the material in the class I tell them any story that related to them. Say for the example in the first meeting we discuss about analytical exposition to make them understand I choose a topic about Pantai JaiJai Raok as we know this beach is very famous recently.)
\end{abstract}

The researcher:

Apa saja biasa kegiatan yang miss terapkan untuk penguatan di dalam kelas?

(Did you implement other activity reinforcement besides telling stories in the class?)

The teacher:

Oh ya dengan bermain atau anak miss lakukan dia langsung turun kelapangan.

(Oh yeah of course, other activity reinforcement that we did was learning outdoor and the students like it the most.)

The interview excerpt above confirms that the teacher used activity reinforcement, these were supported by the statements from the five students. They stated that they often received activity reinforcement in the learning process as follows:

The researcher:
Apakah pada saat pembelajaran miss pernah mengadakan permainan atau aktivitas yang menyenangkan?

(Has your teacher ever held fun games or activities in learning English?)

Student 1:

Pernah, permainan seperti kuis dan sebagainya.

(Yes, the teacher gave us a game like quiz.)

Student 2:

Pernah, Miss pernah melakukan permainan seperti kuis.

(Yes, the teacher ever did a game like quiz.)

Student 3:

Pernah, Miss memberikan kuis kepada kami.

(Yes, the teacher gave us quiz.)

Student 4:

Pernah Miss, bermain kuis.

(Yes the teacher has,)

Student 5:

$Y a$, Miss pernah mengasih permainan seperti kuis.

(Yes, the teacher also gave a game like quiz.)

The researcher:

Bagaimana dengan aktivitas yang menyenangkan seperti apa yang biasanya dilakukan miss?

(How about fun activities, what activities are usually done by the teacher?) 
Dias Frahesti, Harum Natasha - Teacher's Reinforcement in Teaching English at the Second Year of State Islamic Senior High School 2 Kuantan Singingi....

Student 1:

pergi keluar atau praktek langsung tentang pembelajaran.

(By learning outside about what is learned.)

Student 2:

Dengan cara turun langsung kelapangan mempraktekkan pembelajaran yang terjadi.

(By learning outside and practicing the learning that occurs.)

Student 3:

Memberikan aktivitas yang menyenangkan seperti memberikan permainan tentang materi yang sedang dipelajari.

(The teacher provides fun activities such as playing games about the material being studied.)

Student 4:

Pernah, seperti belajar diluar menikmati alam.

(Like studying outside and enjoying nature.)

Student 5:

Oh ya, Miss juga menberikan aktivitas seperti praktek diluar. (Oh yeah, the teacher also provides fun activities such as studying outside.)

To strengthen the results of the research, the researcher also collected the data by observation. Based on the observation, the researcher found that the teacher uses activity reinforcement in teaching English as follows:

Table IV.6

Data Activity Reinforcement

\begin{tabular}{llllll}
\hline \multicolumn{1}{c}{ indicator } & \multicolumn{1}{c}{ Sub Indicators } & 1 & 2 & 3 & 4 \\
& & $\sqrt{2}$ & - & $\sqrt{ }$ & $\sqrt{ }$ \\
Activity & Telling stories & & & & \\
reinforcement & Quiz & - & - & - & $\sqrt{ }$ \\
& Learning outside & & $\sqrt{ }$ & & \\
& & - & & - \\
\hline
\end{tabular}

d. Token Reinforcement

Based on the results of the interview an English teacher about token reinforcement, it can be concluded that the teacher also applied token reinforcement in teaching English. Token reinforcement used by the teacher such as giving star, written comment and gift. This was proved by the interview data with the English teacher as follows:
The researcher:

Apakah miss pernah memberi komentar tertulis atau hadiah lainnya kepada siswa atau sekelompok siswa yang unggul di dalam kelas?

(Have you ever given written comments or given gifts to the 
students who learn

properly in the class?)

The teacher:

Ya... memang pernah, pernah ini, memberikan komentar tertulis itu biasanyaitu bisa kita cek di buku anak, di setiap latikhan-latihan anak, ini ada juga dia sebentuk invitation card dan lainnya, itu baru minggu lalu ya, bab minggu lalu. Tentunya sekarang kita sudah masuk bab baru, itu disetiap ada penilainnya, anak itu memank selalu diberikan, misalnya komentar excellent. Tapi misalnya dia masih very good atau masih good itu diberi anak tuh untuk bimbingan dimana kurangnya, kita kasih komentar.

(Yeah... I have, usually I write down any good comment in their paper when they do the assignment correctly or sometimes I give them to play the card to motivate them. And I always give comments to each student when we turn to the new chapter if some students still get a very good or good category I will give them some advice and asked them what material that they do not understand.)

The researcher:

Hadiah seperti apa yang biasanya miss berikan kepada siswa yang berprestasi di kelas?

(Commonly what kind of gifts do you give to the students who learn properly in the class?)

The teacher:

Hadiah biasanya kami lakukan kalau menang main kuis, itu sering miss kasih sebentuk jajan, jajan-jajan di koperasi, dengan harga mungkin Rp.10.000, mungkin siapa yang dapat menjawab pertanyaan, dia baru dikasih. Kadang pena, buku juga siapa yang bisa menjawab pertanyaan miss, miss sediakan pena.

(Usually for the gift I give it to them who get the highest score in the quiz section. I give them snacks, books and pens.)

The interview excerpt above confirms that the teacher uses token reinforcement, these were supported by the statements from the five students. They stated that they often received token reinforcement in the learning process as follows:

The researcher:

Apakah adik pernah diberi komentar tertulis atau hadiah lainnya ketika menjawab soal dengan benar atau berani maju didepan kelas?

(Have you ever received written comments or gifts when your answer questions correctly?)

Student 1:

Pernah, Miss Dahlia pernah memberikan komentar tertulis seperti excellent, good dan lain-lain. 
Dias Frahesti, Harum Natasha - Teacher's Reinforcement in Teaching English at the Second Year of State Islamic Senior High School 2 Kuantan Singingi....

(Yes I have, the teacher gave me written comments such as excellent, good, etc.)

Student 2:

Pernah, saya pernah mendapat eee... komentar tertulis dari Miss seperti very good dan lain-lain.

(Yes I have, such as good, very good, etc.)

Student 3:

Iya pernah.

(Yes I have.)

Student 4:

Pernah, komentarnya tertulis.

(Yes I have.)

Student 5:

Oh ya, Miss juga pernah menulis komentar seperti good, excellent, dan lain-lain.

(Oh yeah, the teacher also wrote such as good, excellent, etc.)

The researcher:

Bagaimana dengan hadiah, apakah miss pernah memberikannya?

(How about gifts, did the teacher ever give gifts?)

Student 1:

Pernah, aaa ... beerupa benda seperti jajan, pensil, pena dan lain sebagainya.

(Yes the teacher has, aaa... such as snacks, pens, pencils etc.)
Student 2:

Pernah, Miss pernah memberikan hadiah seberti benda yaa... berupa pulpen, jajan dan lain-lainnya.

(Yes the teacher has, such as pens, snacks etc.)

Student 3:

Pernah, Miss memberikan kami pena, pensil dan lain-lain.

(Yes, the teacher gave us pen, pencil etc.)

Student 4:

Pernah Miss, Miss memberikan jajan, snaksnak dan lain-lain.

(Yes, the teacher has, the teacher gives me snacks.)

Student 5:

$Y a$, Miss juga pernah mengasih hadiah seperti pena atau pensil atau jajan-jajan kecil.

(Yeah, the teacher also gives the gifts such as pens, pencils and snacks.)

To strengthen the results of the research, the researcher also collected the data by observation. Based on the observation, the researcher found that the teacher uses token reinforcement in teaching English as follows:

Table IV.7

Data Token Reinforcement

\begin{tabular}{llllll}
\hline \multicolumn{1}{c}{ indicator } & \multicolumn{1}{c}{ Sub Indicators } & 1 & 2 & 3 & 4 \\
\hline $\begin{array}{l}\text { Token } \\
\text { reinforcement }\end{array}$ & Picture cards & - & - & - & - \\
& Written comments & - & $\sqrt{ }$ & - & $\sqrt{ }$ \\
& Gifts & & & & $\sqrt{ }$ \\
& & - & - & & \\
& & &
\end{tabular}

\section{A. Discussion}

This section discusses the findings from in the previous section about teacher reinforcement in teaching English at the second year of State
Islamic Senior High School 2 Kuantan Singingi. In this section, the researcher tries to discuss the research findings with other relevant references. To justify the research findings, the 
researcher tries to discuss them with references to theories related to the answer of the problem statements. The explanation would be presented below:

\section{Verbal Reinforcement}

The researcher analyzed the types of verbal reinforcement given by the teacher in teaching English at the second year of State Islamic Senior High school 2 Kuantan Singingi. In this indicator, the researcher emphasizes observations on two sub-indicators, namely reinforcement with words and reinforcement with sentences.

According to Alma (2014, p.41), the type of verbal reinforcement are reinforcement with word and reinforcement with sentence. Reinforcement with words such as fine, good, great, right and smart. Reinforcement with sentence such as that is a good thought, the way of thinking is very critical, thank you, you are very smart, etc. In this research, the researcher found the types of verbal reinforcement given by the teacher in teaching English.

Based on the interview, the researcher found the implementation of reinforcement with words and reinforcement with sentence in teaching English. Reinforcement with words used by the teacher in teaching English such as "good, smart and great". Reinforcement with sentence used by the teacher in teaching English such as "your answer very good and thank you, you are very smart". This reinforcement was given by the teacher to the students who successfully answer the questions correctly. Based on observations during the 4 meetings that have been conducted by the researcher, the researcher found the teacher always use reinforcement with word and reinforcement with sentence in every meeting.
Based on the result of the research above, the researcher concluded that the teacher in teaching English at the second year of State Islamic Senior High School 2 Kuantan Singingi had implemented the types of verbal reinforcement well.

\section{Non-Verbal Reinforcement}

The researcher analyzed the types of non-verbal reinforcement given by the teacher in teaching English at the second year of State Islamic Senior High school 2 Kuantan Singingi. Based on the interview, the researcher found the implementation of non-verbal reinforcement in teaching English. The teacher used non-verbal reinforcement to improve students' good behavior, maintain their good behavior in the future and remove their bad behavior.

Based on interviews and observations, there were five types of non-verbal reinforcement used by the English teacher at the second year of State Islamic Senior High School 2 Kuantan Singingi. The non-verbal used by the teacher is gestural reinforcement, proximity reinforcement, contact reinforcement, activity reinforcement and token reinforcement. According to Alma (2904, p. 41), There are some types of non-verbal reinforcement namely gestural reinforcement, proximity reinforcement, contact reinforcement, activity reinforcement and token reinforcement.

In using gestural reinforcement the teacher can use expressions and body movements. The teacher reinforced to respond to student behavior with expressions such as "smiling and laughing". While body movements were given by the teacher to respond to students such as "thumbs up, and applause". Proximity reinforcement was done by "walking near students and standing next to students". The teacher also reinforced 
by touching or contacting. The reinforcement was done by the teacher to the students who came bravely to the front of the class. Contact reinforcement was given by teacher such as "tapping the shoulders of the students, shaking hands with students, and high-fiving".

In activity reinforcement, the teacher provided activities that students like. The activity reinforcement used by the teacher in teaching English such as "telling stories, learning outside the classroom and doing quizzes". Based on the findings, the researchers found that the teacher also applied token reinforcement to students in teaching English. The teacher gave rewards to the students who can answer questions correctly. Token reinforcement used by the teacher such as "written comments on student's books and gifts in the form of objects and money".

Based on the result of the research above, the researcher concluded that the teacher in teaching English at the second year of State Islamic Senior High School 2 Kuantan Singingi had implemented the types of non-verbal reinforcement well.

Table IV.8

Teacher Reinforcement in Teaching English

\begin{tabular}{|c|c|c|c|c|c|c|c|}
\hline \multirow{2}{*}{ Indicators } & \multirow{2}{*}{ Sub Indicators } & \multicolumn{4}{|c|}{ Meetings } & \multirow{2}{*}{ Total } & \multirow{2}{*}{$\mathrm{F}$} \\
\hline & & 1 & 2 & 3 & 4 & & \\
\hline Reinforcement & 1. Good & $\sqrt{ }$ & $\sqrt{ }$ & $\sqrt{ }$ & $\sqrt{ }$ & 4 & \\
\hline \multirow[t]{2}{*}{ with word } & 2. Smart & $\sqrt{ }$ & $\sqrt{ }$ & $\sqrt{ }$ & $\sqrt{ }$ & 4 & 11 \\
\hline & 3. Great & $\sqrt{ }$ & - & $\sqrt{ }$ & $\sqrt{ }$ & 3 & \\
\hline \multirow[t]{3}{*}{$\begin{array}{l}\text { Reinforcement } \\
\text { with sentence }\end{array}$} & $\begin{array}{l}\text { 1. Your answer is } \\
\text { correct. }\end{array}$ & - & $\sqrt{ }$ & $\sqrt{ }$ & $\sqrt{ }$ & 3 & \\
\hline & $\begin{array}{l}2 . \text { Thank you, you are } \\
\text { very smart. }\end{array}$ & - & - & $\sqrt{ }$ & $\sqrt{ }$ & 2 & 7 \\
\hline & 3. You so excellent. & $\sqrt{ }$ & - & $\sqrt{ }$ & - & 2 & \\
\hline Gestural & 1. Smile & $\sqrt{ }$ & $\sqrt{ }$ & $\sqrt{ }$ & $\sqrt{ }$ & 4 & \\
\hline \multirow[t]{2}{*}{ reinforcement } & 2. Applause & $\sqrt{ }$ & - & $\sqrt{ }$ & $\sqrt{ }$ & 3 & 10 \\
\hline & 3. Thumbs up & $\sqrt{ }$ & $\sqrt{ }$ & - & $\sqrt{ }$ & 3 & \\
\hline \multirow[t]{3}{*}{$\begin{array}{l}\text { Proximity } \\
\text { reinforcement }\end{array}$} & $\begin{array}{l}\text { 1. Walking towards } \\
\text { students }\end{array}$ & $\sqrt{ }$ & $\sqrt{ }$ & $\sqrt{ }$ & $\sqrt{ }$ & 4 & \\
\hline & $\begin{array}{l}\text { 2. Standing near } \\
\text { students }\end{array}$ & $\sqrt{ }$ & - & $\sqrt{ }$ & $\sqrt{ }$ & 3 & 8 \\
\hline & 3. Sitting near students & - & $\sqrt{ }$ & - & - & 1 & \\
\hline \multirow[t]{3}{*}{$\begin{array}{l}\text { Contact } \\
\text { reinforcement }\end{array}$} & $\begin{array}{l}\text { 1. Tap the student's } \\
\text { shoulder }\end{array}$ & $\sqrt{ }$ & - & $\sqrt{ }$ & $\sqrt{ }$ & 3 & \\
\hline & 2. High five & $\sqrt{ }$ & - & - & $\sqrt{ }$ & 2 & 6 \\
\hline & 3. Shake hands & - & - & $\sqrt{ }$ & - & 1 & \\
\hline Activity & 1. Telling stories & $\sqrt{ }$ & - & $\sqrt{ }$ & $\sqrt{ }$ & 3 & \\
\hline \multirow[t]{2}{*}{ reinforcement } & 2. Quiz & - & - & - & $\sqrt{ }$ & 1 & 5 \\
\hline & 3. Learning outside & - & $\sqrt{ }$ & - & - & 1 & \\
\hline Token & 1. Picture cards & - & - & - & - & 0 & \\
\hline \multirow[t]{3}{*}{ reinforcement } & 2. Written comments & - & $\sqrt{ }$ & - & $\sqrt{ }$ & 2 & 3 \\
\hline & 3. Gifts & - & - & - & $\sqrt{ }$ & 1 & \\
\hline & TOTAL & & & & & 50 & 50 \\
\hline
\end{tabular}


Based on the observation during 4 meetings, it was found that the English teacher at the second year of State Islamic Senior High School 2 Kuantan Singingi used all the reinforcement components in the process of teaching learning English.

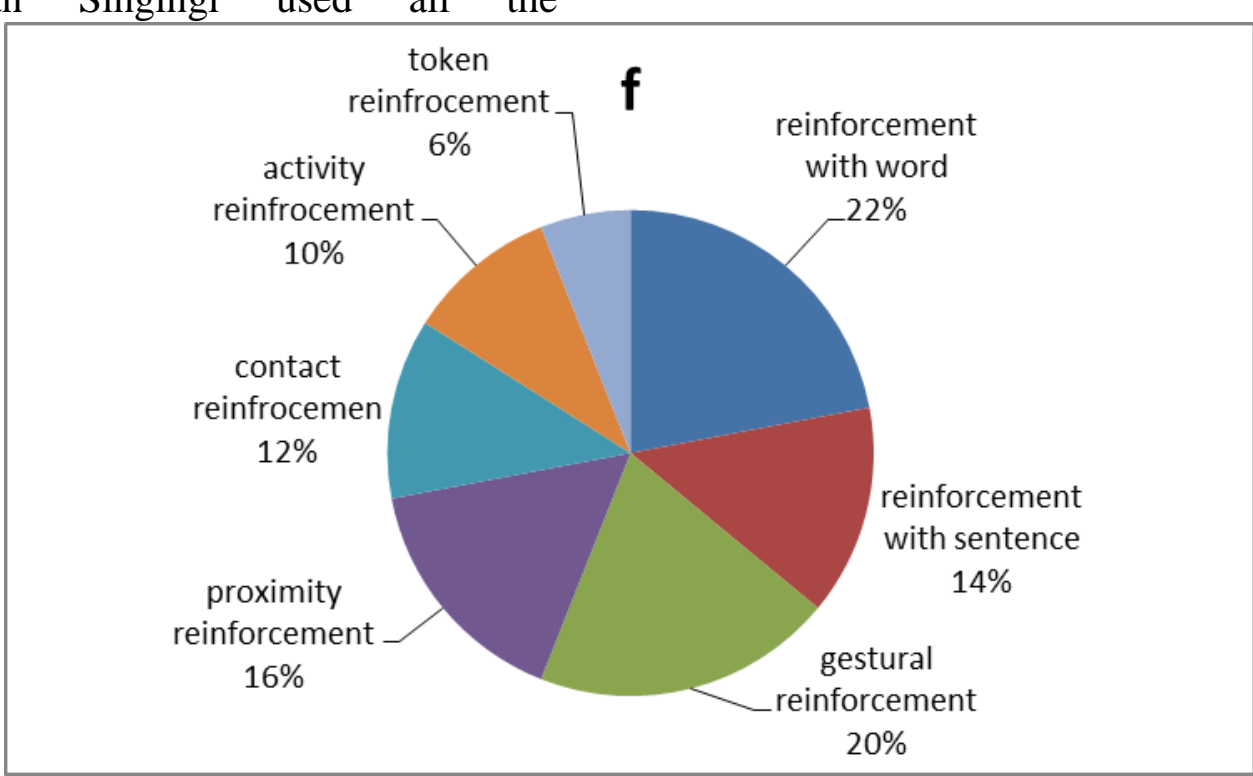

Based on the pie chart above, the results show that the teacher reinforcement with words was $22 \%$, reinforcement with sentence was $14 \%$, gestural reinforcement was $20 \%$, proximity reinforcement was $16 \%$, contact reinforcement was $12 \%$, activity reinforcement was $10 \%$ and token reinforcement was $6 \%$. Based on the observation, it can be concluded that the components of reinforcement mostly often used by the teacher in teaching English is reinforcement with words $(22 \%)$, whereas reinforcement that is rarely used by the teacher is token reinforcement $(6 \%)$.

\section{A. Conclusion}

Based on the results of the research, it can be concluded that the English teacher at the second year of State Islamic Senior High School 2 Kuantan Singingi has successfully applied the components of reinforcement in teaching English. Reinforcement is given by the teacher as a response to the student behavior, such as students can answer the teacher question correctly and students who dare to come to the front of the class. The application of teacher's reinforcement in teaching English at the second year of State Islamic Senior High School 2 Kuantan Singingi consist of verbal reinforcement and non-verbal reinforcement.

The application of verbal reinforcement is done by reinforcement with words and reinforcement with sentence. Reinforcement with words is done by the teacher by giving praise such as "good, smart and great". Reinforcement with sentence is done by the teacher by giving praise such as "your answer is correct, thank you, you are very smart and you so excellent".

The application of non-verbal reinforcement is done by providing reinforcement of gestural, proximity, contact, activity and token. Gestural reinforcement is done by the teacher with "a smile, applause and thumbs 
up". Proximity reinforcement is done by "the teacher walking toward students, standing near students and sitting near groups". Contact reinforcement is done by the teacher with "tapping on the shoulder, shaking hands and giving high fives to students". Activity reinforcement is done by the teacher with "telling stories, doing games/ quizzes and learning outside”. Token reinforcement is done by the teacher with "giving written comments and gifts".

Based on the observation the results show that the teacher's reinforcement with words was $22 \%$, reinforcement with sentences was $14 \%$, gestural reinforcement was $20 \%$, proximity reinforcement was $16 \%$, contact reinforcement was $12 \%$, activity reinforcement was $10 \%$ and token reinforcement was $6 \%$. Based on the observation, it can be concluded that the components of reinforcement mostly often used by the teacher in teaching English is reinforcement with words $(22 \%)$, whereas reinforcement that is rarely used by the teacher is token reinforcement $(6 \%)$.

\section{REFERENCES}

Alma, Buchari. (2014). Guru Profesional: Menguasai Metode dan Terampil Mengajar. Bandung: Alfabeta.

Ary, D. et al. (2010). Introduction to research in education. Canada: Wadsworth.

Arikunto. (2006). Motode Penelitian Kualitatif. Jakarta: Bumu Aksara.

Arikunto, Suharsimi. (2002). Prosedur Penelitian Suatu Pendekatan Praktek. Jakarta: Rineka.
Asril, Z. (2011). Micro Teaching: Disertai dengan Pedoman Pengalaman Lapangan. Jakarta: Rajawali Pers.

Creswell, John W. (2012). Educational research: Planning, conducting and evaluating quantitative and qualitative research. Berlin : New Jersey.

Helmiati.

(2013).Micro

Teaching:Melatih Keterampilan Dasar Mengajar. Yogyakarta: Aswaja Pressindo.

Hoque, R. (2013). Effect of reinforcement on teaching learning Process. IQSR Journal of Humanities and Social Science, 7(1), 13-16.

Lefrancois, R. G. (2000). Theories of human learning: What the old man said. Fourth edition. Amerika: Thomson Wadsworth.

Moleong. (2006). Metodologi Penelitian Kualitatif. Bandung: PT. Remaja Rosdakarya.

Miles, M.B. \& Huberman, A.M. (1994). Qualitative data analysis. $2^{\text {nd }} \mathrm{ed}$. USA: Sage Publication.

Pratiwi, M. B. A. et al.(2018). A study of the reinforcement used by English teacher in 6A class at SD Undiksa Singaraja. ISSN: 2549-4287. Vol. 2.

Putro, Eko W. (2017). Teknik Penyusunan Instrument Penelitian. Yogyakarta: Pustaka Pelajar.

Santrock, John W. (2011). Educational psychology $\left(5^{\text {th }}\right.$ ed). New York: Mc Graw Hill. 
Dias Frahesti, Harum Natasha - Teacher's Reinforcement in Teaching English at the Second Year of State Islamic Senior High School 2 Kuantan Singingi....

Skinner, B. F. (2014). Science and human behavior. London: Pearson Education.

Slavin, Robert E. (2006). Educational psychology; Theory and practic ( $8^{\text {th }}$ edition). Boston: Pearson.

Sugiyono. (2007). Metode Penelitian Kuantitatif Kualitative dan $R \& D$. Bandung: Alfabeta.

Usman, M. Uzer. (2010). Menjadi Guru Profesional: Edisi Kedua. Bandung: Remaja Rosdakarya.

Wahyudi, Deddy., et al (2013). An analysis of reinforcement implementation by English teacher at SMAN 1 kecamatan V Koto Kampung Dalam Padang Pariaman Regency. Journal English Language Teaching (ELT). Vol. 1. No. 2.
Walker, S. (1975). ESSENTIAL PSYCHOLOGY edited by peter herriot learning and reinforcement. London: Methuen \& Go Ltd.

Woolfolk, A. (2007). Educational psychology. Australia: Pearson Educational.

Zebua, Kefas A. D. P. (2017). The use of verbal reinforcement to motivate the $11^{\text {th }}$ grade students of SMA Dudya Wacana Yogyakarta to speak English. Yogyakarta. Published Thesis.

Zhou, Molly Y \& Brown, D. (Eds). (2017). Educational learning theories. Retrieved From [https://oer.galileo.usg.edu/educ ation-textbooks]. 